\title{
Sustainability Accounting Concept in Higher Education Institution: A Case Study of an Indonesian Public University
}

AFFILIATION:

Faculty of Economics and Business, Universitas Pendidikan Ganesha, Indonesia

\section{*CORRESPONDENCE:}

putusukma@undiksha.ac.id

THIS ARTICLE IS AVAILABLE IN:

https://ojs.unud.ac.id/index.php/jiab

DOI:

10.24843/JIAB.2020.v15.i02.p06

\section{CITATION:}

Kurniawan, P. S. (2020).

Sustainability Accounting Concept in Higher Education Institution: A Case Study of an Indonesian Public University. Jurnal IImiah Akuntansi dan Bisnis, 15(2), 213-233.

\section{ARTICLE HISTORY}

Received:

05 December 2019

Revised:

15 January 2020

Accepted:

05 April 2020
Putu Sukma Kurniawan*

\begin{abstract}
The change in the accounting paradigm has now shifted from conventional accounting to sustainability accounting. This study seeks to develop a model for implementing sustainability accounting in educational sector organizations. The site of this research is Universitas Pendidikan Ganesha, Bali. This research used a qualitative approach. This research is divided into two main stages. The first stage is the stage of observation regarding the current accounting system. At this stage, data will be searched for the development of the sustainability accounting implementation model. The method of collecting data in the first stage is to conduct interviews, observation, and document analysis. The second stage is the stage for designing the sustainability accounting implementation model. The output of this research is a concept or model regarding the application or implementation of sustainability accounting in the activities of educational sector organizations. The results of this study are expected to provide guidelines for educational sector organizations (universities) in the context of applying sustainability accounting concept. The implication of this research is to promote the implementation of sustainability accounting in nonbusiness organization, particularly in higher education institution.
\end{abstract}

Keywords: Public university, sustainability accounting, sustainability accounting implementation model.

\section{Introduction}

The application of sustainability accounting has many benefits for the organization. The concept of sustainability accounting not only focus on the company's financial values, but also focuses on the company's sustainability strategy. At present, the company's management has applied many concepts of sustainability to the company's business activities and is committed to disclose the social and economic impacts of the company's business activities. By applying the concept of sustainability accounting, the company's management has linked the company's business strategy with the sustainability framework and this process will make the company not only focus on the financial impact, 
but also consider the social and environmental impacts of every business decision conducted by the company's management. The AICPA (American Institutes of CPAs) organization states that the scope of sustainability accounting includes how to link sustainability principles with the company's business strategy, the business risk evaluation process, and the accounting measurement process within the company. This process will ensure that every business activity of the company will be based on the principles of sustainability. Some examples of the application of sustainability accounting according to the AICPA are the use of flexible budgeting to improve sustainability measurement and measurement techniques for environmental sustainability. The concept of sustainability accounting has now become an interesting issue that has been discussed by professional accountants. The problem in conventional accounting is that conventional accounting cannot measure company activities that are not quantitative, but these activities can add value to the company. Examples of these activities are the impact of the company's business activities on the social and environmental community, the company's relationship with customers, strong commitment from employees, and high motivation of company management are the company activities that cannot be measured by numbers. This information is important for the company's stakeholders and the concept of sustainability accounting can present this type of information. The role of the stakeholders will determine the quality of the implementation of sustainability accounting concept in an organization. Research from Kaur \& Lodhia (2018) showed that corporate stakeholders play an important role in implementing sustainability accounting primarily in the process of reporting the social and environmental information, developing strategic plans and sustainability indicators, measuring sustainability performance, and preparing organizational sustainability reports.

Currently, there are specific standards or guidelines regarding the implementation of sustainability accounting, both for business organizations and nonbusiness organizations. The organization that is highly committed to implementing sustainability accounting, SASB (Sustainability Accounting Standard Board), has set standards for implementing sustainability accounting based on each industry. This is a very good process considering, in the context of accounting, an accounting practice will be easy to implement if there are already established standards to help the accounting practices. The existence of standards on sustainability accounting can certainly be an initial stimulus for various business organizations and non-business organizations to implement the concept of sustainability accounting in their organizational activities. To support the implementation of the concept of sustainability accounting in non-business organizations, SASB has issued standards for implementing sustainability accounting in the field of education (education organization). Based on sustainability accounting standards which released by SASB, there are two scopes of information that must be disclosed by organizations in the field of education. The first scope covers sustainability disclosure topics and accounting metrics which include information on data security, quality of education \& gainful employment, and marketing \& recruiting practice. The second scope covers activity metrics which include information about number of students enrolled and number of applications received for enrollment. The sustainability concept has implemented in the public sector organizations. Governments from various countries also committed to the implementation of sustainability accounting by 


\section{Kurniawan}

Sustainability Accounting Concept in Higher Education Institution: A Case Study of an Indonesian Public University

compiling various guidelines and standards on the implementation of the concept of sustainability accounting. The Government of Japan through the Ministry of Environment developed environmental accounting guidelines (Environmental Accounting Guidelines) in 2005 and the New Zealand Government issued guidelines on social costs in the Guide to Social Cost-Benefit Analysis in 2015. The existence of these rules indicates that governments in various countries have committed and high motivation to implement the concept of sustainability accounting.

The concept of sustainability accounting can be applied to organizations other than business organizations. One derivative of the practice of sustainability accounting is to disclose financial information, social information, and environmental information in the corporate sustainability reporting. Domingues et al. (2017) discusses the practice of disclosure of sustainability reporting in public sector organizations. The results of the study of Domingues et al. (2017) showed that the practice of implementing information disclosure through corporate sustainability reporting can have an impact on an organization's internal business processes and is strongly influenced by the role of the organizational stakeholders. Research conducted by Farneti \& Guthrie (2009) examined information disclosure practices through sustainability reporting in public sector organizations in Australia. This research found that sustainability reporting carried out within public sector organizations is very beneficial for all organizational stakeholders. Other research conducted by Adams et al. (2014) which examines the measurement of sustainability performance of public sector organizations. Research from Adams et al. (2014) found that measurement of sustainability performance in public sector organizations can focus on aspects of sustainability, environmental responsibility, and social responsibility. Other research from Adams (2013) aims to develop the concept of sustainability reporting for universities and this research has implications for university policy in the context of applying the concept of sustainability.

Based on the research background that has been explained, this research focuses on developing a model or concept to implement the concept of sustainability accounting in the accounting system of a public university. This research will try to integrate the accounting system currently applied in the site of research with the concept of sustainability accounting. Some reasons why this research focuses on drafting the concept of implementing sustainability accounting at public universities are (1) the concept of sustainability accounting is now a reference for business organizations and non-business organizations as a guide for implementing the concept of sustainability in organizations, (2) the existence of guidelines and standards regarding implementation sustainability accounting at educational institutions, and (3) educational institutions (universities) should be the first institution in the context of non-business organizations to implement the concept of sustainability accounting because studies on sustainability accounting are inseparable from the role of academics at universities. The preparation of this research is also based on research conducted by Lange \& Kerr (2013) which examines how to form accounting practices that are consistent with the concept of sustainability in the tertiary education environment. The results of Lange \& Kerr (2013) found that there are accounting processes in the tertiary education environment that actually hinder the application of the concept of sustainability in university activities and university leaders should prepare a concept of sustainability reporting. Based on the background, this research is expected to produce a model that can later be used as a 
guideline for educational sector organizations in the context of applying sustainability accounting. The research location is in Universitas Pendidikan Ganesha, Bali, Indonesia. The Universitas Pendidikan Ganesha is a public university which located in the heart of Singaraja, Bali. The main reason to choose this public university is the Universitas Pendidikan Ganesha has the vision and mission based on the concept of Tri Hita Karana. The concept of Tri Hita Karana is the main concept in the Balinese daily activity and has been implemented as the life guideline in Bali. The concept of Tri Hita Karana means the source of happiness and the concept of Tri Hita Karana is divided into three little concepts: Parahyangan, Pawongan, and Palemahan. Parahyangan describes the way to create the good relationship with the God. In this context, Parahyangan shows religion and culture. Pawongan describes about how to build a good relationship in our social community. And Palemahan shows the way to create a good relationship between people and their environment. Creating the good relationship with the God, building the good connection with the social community, and creating the good relationship with the environment are the source of happiness for Balinese and this concept is the heart of Tri Hita Karana. If we create the connection between the concept of Tri Hita Karana and the sustainability accounting concept, we will find that the two concepts have the same spirit. Tri Hita Karana and the sustainability accounting concept describes the procedure for the human and business system to create a perfect relationship with the social community and the environment. With this perspective, it is a perfect combination if this research chooses the Universitas Pendidikan Ganesha as a research location because the university's vision and mission.

This research aims to develop a concept of sustainability accounting that can be applied to research object. The concept of sustainability accounting has now been widely applied, especially to organizations with a high commitment to the concept of sustainability. Public university organizations are one example of organizations that implement accounting systems and a university can be a pioneer in the context of implementing the concept of sustainability accounting. This research focuses on making guidelines in implementing sustainability accounting for non-business organizations, especially universities. This research also aims to prove the impact of applying sustainability accounting for organizations. By using impact analysis, this research tries to analyze the benefits of what an organization will get if it applies the concept of sustainability accounting to the organization's activities. This research aims to promote the application of sustainability accounting in various organizations by providing a positive impact on the organization if it applies the concept of sustainability accounting to organizational activities. This research has the aim to assist the development of literature related to the concept of sustainability accounting. The results of this research can later be used as a reference regarding the implementation of the concept of sustainability accounting in an organization. The issue of the concept of sustainability accounting is now a new concept and this topic is an interesting research topic to develop in the future. The results of this study can be used as a research references and references for implementing the concept of sustainability accounting, especially in higher education institutions.

This research can provide theoretical benefits related to the concept of sustainability accounting, especially theories about the implementation or application of sustainability accounting in non-business organizations. The topic of sustainability 
accounting still has an ample room for a research in the future. This research is expected be able to contribute to the development of literature, especially literature related to the concept of sustainability accounting. This research is expected to provide a new perspective on the implementation of the concept of sustainability accounting in nonbusiness organizations. The results of this study can be used as a guide or reference for organizations (mainly educational sector organizations) to implement the concept of sustainability accounting in the organization's accounting system. One of the fundamental problems in implementing a new accounting system is the absence of guidelines or references that help organizations to understand the new accounting system. The concept of sustainability accounting has now begun to develop and more and more organizations are committed to applying the concept of sustainability accounting in their organizational activities. The results of this research will provide practical benefits in the context of helping organizations to implement the concept of sustainability accounting in organizations.

This research is expected to contribute to policies related to the implementation of sustainability accounting in organizations in Indonesia. Some organizations that create the accounting systems, for example SASB (Sustainability Accounting Standard Board), have released standards or guidelines regarding the implementation of the concept of sustainability accounting for business organizations and non-business organizations. The existence of standards or guidelines regarding sustainability accounting shows that more and more organizations are committed to applying the concept of sustainability accounting to the organizational activities. The policy regarding the implementation of sustainability accounting is not only prepared for business organizations, but later this policy can be used in non-business organizations. One of the things that can be done so that the process of implementing the concept of sustainability accounting is widely applied by organizations is by issuing guidelines or standards regarding the implementation of sustainability accounting concepts.

\section{Research Method}

The framework in this research was formed through an understanding that the concept of sustainability accounting can be applied to all organizations, both business organizations and non-business organizations. By using this logic, it can be understood that every organization has the ability to implement the concept of sustainability accounting in the organizational activities. The process of implementing sustainability accounting is not understood by making a total replacement to the accounting system that has been implemented by the company. The process of implementing sustainability accounting in an organization must pay attention to (1) the current accounting system in the organization and (2) the characteristics of the organization. This research framework is also based on the concept from the research of Adams et al. (2014) which states that all organizations can implement the concept of sustainability accounting in the organization's business activities and research from Lange \& Kerr (2013) which states that there are several accounting processes in the tertiary education environment that actually hinder the application of the concept of sustainability in universities.

Implementation of the concept of sustainability accounting in this research includes two main parts, namely (1) the process for identifying social and environmental costs in university activities and (2) identification of material information which will later 
be disclosed in the university's sustainability report. The process of identifying social costs and environmental costs is intended to see and determine the social costs and environmental costs that arise from activities within the university. The next implementation is related to the preparation of university sustainability reports in which this process identifies the types of information that will later be disclosed in the university's sustainability report. This research framework draws reference from research conducted by Adams (2013) which focuses on integrating the concepts of sustainability in the university's internal business processes. Research from Adams (2013) found that the practice of sustainability in the tertiary education environment is far behind that of other organizational sectors and this research has high motivation to help develop the concept of implementing sustainability accounting in the tertiary education environment (university). This research framework is also based on the results of research conducted by Lozano (2006) who made a model of assessing sustainability performance in higher education institutions. This research will try to apply the sustainability performance assessment model that has been prepared to evaluate the sustainability performance of the research object.

This research is based on a qualitative perspective. The design of this study refers to the research design conducted by Kaur \& Lodhia (2018) who uses a case study research design. The case study research design in this research was used to develop the concept of implementing sustainability accounting on the research object. This study also uses the Graphical Assessment of Sustainability in Universities (GASU) method which developed by Lozano (2006) to assess the level of application of the concept of sustainability in the research object. The scope of this research consists of two main parts, namely (1) identification of social costs and environmental costs and (2) identification of material information about economic performance, social performance, and environmental performance which can later be disclosed in the university's sustainability report. The scope of this research covers several aspects First, Identify the social costs and environmental costs contained in organizational activities at the Universitas Pendidikan Ganesha. The identification of social costs will be based on the Guide to Social Cost-Benefit Analysis released by the New Zealand Government and identification of environmental costs will be based on the Environmental Accounting Guidelines issued by the Japanese Ministry of Environment. The identification process regarding social costs and environmental costs is also guided by the research of Petcharat \& Mula (2012) who developed a system design for the identification and measurement of social costs and environmental costs. Second, Conduct an assessment of the sustainability performance of the Universitas Pendidikan Ganesha using the GASU method and the STARS systems. This assessment process is important to see and evaluate whether the current accounting practices at universities are in accordance with the principles and concepts of sustainability accounting. Third, Identifying material information in the economic, social and environmental fields to later be disclosed in the Universitas Pendidikan Ganesha's sustainability report. Lozano (2011) research proves that educational institutions, such as universities, in the future have excellent potential for disclosing information to stakeholders through a sustainability report.

This research was conducted at Universitas Pendidikan Ganesha by focusing on the implementation of the concept of sustainability accounting. Some reasons for this research conducted at Universitas Pendidikan Ganesha, namely (1) the university's 


\section{Kurniawan}

Sustainability Accounting Concept in Higher Education Institution: A Case Study of an Indonesian Public University

vision and mission is based on the Tri Hita Karana concept and the concept of Tri Hita Karana is appropriate with the spirit of sustainability accounting, (2) SASB's sustainability accounting standards provide standards that can be applied to organizations nonbusiness, in this case is an educational organization, and (3) Universitas Pendidikan Ganesha has very good carrying capacity to apply the concept of sustainability accounting based on the university's long-term plan. Another reason that made researchers choose the university as the object of research is none other than the motivation of researchers to develop the concept of sustainability accounting in educational sector organizations. During this time, the process of implementing or applying the concept of sustainability accounting has always focused on business organizations (private companies) and this research takes up another space by trying to develop the concept of implementing sustainability accounting in non-business organizations (universities). Universities have an important role to play in developing sustainability accounting practices and this process will be very helpful for other nonbusiness organizations to implement the concept of sustainability accounting in organizational activities. The key informants in this research is the vice rector of finance and general administration, the head of finance department, the accounting staff in the university's head office, and the accounting staff in each faculty.

This research requires comprehensive data as material to formulate the concept of implementing sustainability accounting at Universitas Pendidikan Ganesha. For the first part of this research (identification of social costs and environmental costs), the data needed are documents relating to the accounting system currently in force at Universitas Pendidikan Ganesha. The documents are the university financial statements, performance reports in each section or division, operational standards and procedures that apply to the accounting system, and other documents related to the ongoing accounting system. This research also requires other documents outside the accounting context, for example documents regarding future university development plans, university vision and mission documents, and reports on social and environmental activities that have been carried out by the university. For the second process of this research (identification of types of material information), this research requires data related to financial performance information, social performance information, and environmental performance information. Some examples of the data needed are documents about social activities that have been carried out by universities, documents regarding environmental activities that have been carried out by universities, and documents that show the commitment of university leaders to the implementation of sustainability principles.

There are several stages of data analysis in this research. The stages of this research, First, Identifying social costs and environmental costs contained in the Universitas Pendidikan Ganesha activities. This identification process is guided by the Guide to Social Cost-Benefit Analysis and Environmental Accounting Guidelines. Data analysis was carried out by looking at the accounting system documents at the university and then analyzing what social costs and environmental costs arose from the university activities. Second, Assessing the sustainability performance of research object using the Graphical Assessment of Sustainability in Universities (GASU) which developed by Lozano (2006) and using the STARS system which developed by AASHE. This research uses the GASU guidelines because the GASU guidelines have become the main 
guidelines that can be used to assess the sustainability performance of a university. The research arguments for using the STARS system are (1) STARS system provides a clear framework for understanding sustainability performance, especially in tertiary education organizations, (2) the results of performance measurement can be compared with some of the sustainability performance of other educational organizations, and (3) provide input and suggestions for the development of organizational sustainability performance in the future. This stage can later assist in the process of identifying information that will be disclosed in the organization's sustainability report. Third, Identifying the types of material information (financial information, social information, and environmental information) that will later be disclosed in the organization's sustainability report. The information criteria that will be disclosed in the university's sustainability report will be based on several sustainability reports that have been produced by several other universities.

\section{Result and Discussion}

The next step in this research is to develop a model or framework for the implementation or application of sustainability accounting at Universitas Pendidikan Ganesha. In general, this arrangement model will cover four activities. These activities are (1) identification of social costs and environmental costs contained in the university's internal business activities, (2) the process of identifying the sustainability performance of universities with the Graphical Assessment of Sustainability in Universities (GASU) and STARS systems, and (3) identifying financial and non-financial information from the university. Process number 3 will produce a concept regarding sustainability reporting from the university. At present, Universitas Pendidikan Ganesha does not yet have a concept regarding sustainability reporting that can be published publicly. The results of this research can be used as a reference by the university leaders in the process of preparing university sustainability reports and at the same time increasing the flow of information from the university to all university stakeholders.

The main concept of sustainability accounting is the inclusion of measures of social costs and environmental costs in the organization's accounting system. Social costs and environmental costs can be defined as impacts in social and environmental communities (both monetary and non-monetary) that must be borne as a result of the organization's business activities. In this context, the role of sustainability accounting is to identify and measure the social costs and environmental costs resulting from the organization's business activities. This research will identify the social costs involved in operational activities of the Universitas Pendidikan Ganesha. During this time, the university has made a budget regarding the costs incurred for environmental management within the university. An interview with staff in the finance department of the Universitas Pendidikan Ganesha stated that,

"We in the finance department are not familiar with the term of social costs in university operations. In the accounting guidelines for universities, the term social costs are unknown. For environmental costs we seem to have, maybe the costs incurred for structuring parks in the campus environment. "

Based on the results of this interview, it can be understood that the university has not identified the social and environmental costs. In this research, identification of social costs will be carried out using the Guide to Social Cost-Benefit Analysis (GSCBA) 
which issued by the Government of New Zealand. The GSCBA Guidelines are used because this guideline includes guidelines on identifying social costs that can be used by public sector organizations. The GSCBA Guidelines are generally used to analyze social costs and benefits arising from government policies. In general, the guidelines for identifying social costs in accordance with the GSCBA guidelines consist of three stages. The three stages are (1) identification of parties in the social community who are having adverse effects from the activities of the organization, (2) identification of costs that must be incurred to control these adverse impacts, and (3) quantification of social costs that must be incurred.

The first stage to identify social costs is to identify the parties in the university social community that are adversely affected by the university's operational activities. Based on the GSCBA guidelines, parties that can be said to have a bad impact are those who are affected (especially negative impacts) due to university policy or due to university operational activities. Examples of parties from the affected social community are the people around the campus who have had to move due to university development activities or the community in the social community affected by trash or waste generated by the university. To obtain information about parties from social communities affected by the university activities, researcher conducted interviews with the Head of the General and Financial Bureau of the Universitas Pendidikan Ganesha who stated that

"So far, the university has not received complaints or complaints from the community due to university activities. The campus development process carried out also received support from the community and so far, we have not received reports of communities having a negative impact from university activities "

Based on the results of this interview it can be understood that so far, the university has never received complaints from the social community due to the university's operational activities. This can be understood given the characteristics of the business lines of a university. The concept of social costs initially arose from industrialization activities which produced negative externalities for the social community around the industrialization. A university is less likely to produce negative externalities for its social community. Based on this understanding, the concept of social costs in the concept of sustainability accounting at universities is not the costs incurred to minimize the negative impact of company activities, but rather a social investment made by the university.

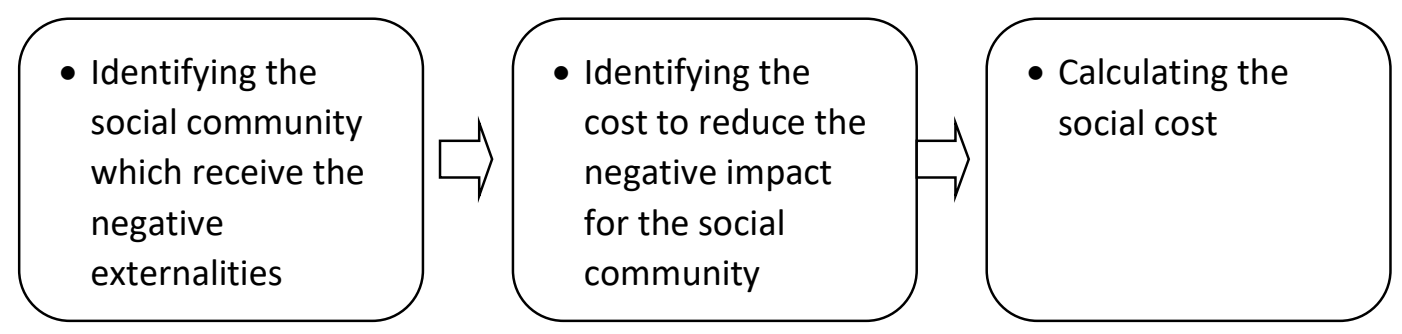

Figure 1. Stage to Identify the Social Cost

Source: Processed Data, 2019 
This can be understood because organizations engaged in the education sector do not produce a negative externality for the social community. This will be inversely compared to business organizations engaged in the mining or manufacturing sectors which directly and indirectly, the company's business activities can produce negative externalities for the social community around the company.

Research from Cohn \& Geske (1990) states that in general there are two types of cost categories in the higher education system, namely direct costs and indirect costs. The practice of determining unit costs in the higher education system has been widely practiced by universities in the United States. This research identifies direct and indirect costs based on budget reports from the University of Louisiana at Lafayette. The University of Louisiana has divided the types of direct and indirect costs.

Direct costs in the tertiary education system are types of costs directly related to the main task of tertiary institutions (Tri Dharma Perguruan Tinggi), namely the costs used for the implementation of teaching and education, research, and community service. Examples of these direct costs are salaries/wage which is the salary of professional lecturers and employees, materials and supplies which include materials used for research activities, equipment that includes technical equipment and other equipment for educational and research activities, travel which covers the campus staff's travel costs in the context of official travel, publications that include research publication costs for university staff.

Indirect costs are types of costs that cannot be easily identified and types of costs that cannot be accurately associated with the cost object. In the context of the higher education system, indirect costs in university operational activities include depreciation of buildings and equipment, general administrative costs, operating and maintenance costs, administrative costs, service costs to students, building repair costs, and promotion costs for departments and universities.

In the context of university social responsibility, the university has carried out several activities that contribute to the social field (university social responsibility program). Contributions to the social field have become part of the university's vision and mission. One of the activities of the university's social responsibility is to carry out the fostered village program which is one with community service activities. Social activities carried out by the university cannot be included as a cost component in organizational activities. Costs incurred in this activity have been budgeted and basically this activity is part of the main tasks of the tertiary education institution.

The next stage in this research is to identify environmental costs in university operations. Environmental costs are costs that must be incurred by organizations related to environmental damage or to protect the environment from damage caused by the organization's business activities. Environmental costs in general can be divided into two types, namely internal environmental costs and external environmental costs. Internal environmental costs are a number of costs that must be incurred by the organization so that the production process within the organization has a small impact on the environment around the organization. External environmental costs are a number of costs that must be incurred by the organization to repair the environmental damage caused by the company's business activities. 
Table 1. Types of University's Environmental Cost

\begin{tabular}{|c|c|c|}
\hline Numbe & Types of Environmental Cost & Related Activities \\
\hline 1. & $\begin{array}{l}\text { Environmental costs for } \\
\text { environmental prevention and } \\
\text { management }\end{array}$ & $\begin{array}{l}\text { a) Management and arrangement of } \\
\text { parks and plants throughout the } \\
\text { campus environment } \\
\text { b) Management of building } \\
\text { cleanliness in the rectorate, } \\
\text { faculties, and departments } \\
\text { c) Waste management and disposal } \\
\text { activities }\end{array}$ \\
\hline 2. & Cost of environmental detection & $\begin{array}{l}\text { d) Testing water quality in the } \\
\text { campus environment } \\
\text { e) Testing air quality in the campus } \\
\text { environment }\end{array}$ \\
\hline 3. & $\begin{array}{l}\text { Cost of internal environmental } \\
\text { failure }\end{array}$ & $\begin{array}{l}\text { f) Maintenance of cleaning tools and } \\
\text { machines }\end{array}$ \\
\hline 4. & $\begin{array}{l}\text { Cost of external environmental } \\
\text { failure }\end{array}$ & $\begin{array}{l}\text { g) Cannot be identified because there } \\
\text { is no clear activity }\end{array}$ \\
\hline
\end{tabular}

Source: Processed Data, 2019

In general, companies that have a high concern for the concept of sustainability will allocate a budget for internal environmental costs. This is based on the fact that the costs of the external environment are relatively greater than the costs of the internal environment.

The types of environmental costs contained in the activities of educational sector organizations are (1) environmental costs for environmental prevention and management, (2) environmental detection costs, (3) environmental internal failure costs, and (4) external environmental failure costs. Types of costs such as environmental costs for environmental prevention and management are standard costs found in higher education organizations. This type of cost is needed to maintain the environmental conditions around the company. Universitas Pendidikan Ganesha in its activities does not produce hazardous waste to the environment and this results in types of costs such as the cost of internal environmental failure and the cost of external environmental failure having a smaller cost component. The Table 1. explain the cost components and the activities associated with these cost components.

Based on Table 1. it can be seen that the types of environmental costs that are commonly found in higher education sector organizations are costs for environmental prevention and management and environmental detection costs. This analysis is based again on the characteristics of universities whose activities do not produce waste and products that are harmful to the environment.

The stages of this research are aimed at evaluating the sustainability performance of the Universitas Pendidikan Ganesha. This assessment stage is very important to see whether the sustainability performance of the Universitas Pendidikan Ganesha is at a good level or not. The results of this stage will provide an evaluation for the university regarding the sustainability performance that has been carried out by the university. The results of this stage are also important as a basis in the context of the disclosure of financial and non-financial information of the university in the university's sustainability report. In theory, if an organization has good sustainability performance, then the organization will tend to further expand the disclosure of financial and nonfinancial information in the organization's sustainability report. The identification process of the university's sustainability performance will use two indicators namely 
Graphical Assessment of Sustainability in Universities which developed by Lozano (2006) and STARS system (Sustainability Tracking, Assessment \& Rating System) which developed by AASHE (The Association for the Advancement of Sustainability in Higher Education). Lozano (2006) states that the GASU indicators that have been developed will provide a systematic assessment process and the results can be used as a basis for preparing a university sustainability report. In general, sustainability performance assessment indicators from GASU have 5 performance measures, namely (1) profile, (2) economic, (3) environmental, (4) social, and (5) educational. To conduct an analysis using GASU, this research uses secondary data from the university's official website and related reports or documents that have been published by the university. Based on the GASU guidelines, the values of performance indicators are 43 for the profile, 9 for the economic field, 30 for the environmental field, 40 for the social sector, 29 for the education sector, and 23 for the interlinked issues and dimensions field. Each indicator in the GASU guidelines is analyzed using the guidelines (1) a value of 0 is given if information regarding the indicator is missing or not found in the university report, (2) a value of 1 is given if the information states poor performance. Information is general and not detailed, (3) a value of 2 is given if the information states regular/fair performance. Information is general, still covers half of the topic, and has not been detailed, (4) a value 3 is given if the information states good performance. The information is detailed and includes the issues discussed, (5) a value of 4 is given if the information states excellent performance. The information presented is complete and detailed for one indicator.

Based on GASU guidelines and assessment guidelines, an analysis of the sustainability performance of the university is carried out. The results of the analysis are presented in the Table 2.

Based on the general chart generated from the analysis, it can be concluded that basically the Universitas Pendidikan Ganesha has had a good sustainability performance. The good university sustainability performance is shown in the social and educational fields, especially in the creation of healthy work environment practices, recognition of human rights, curriculum development, and research related to sustainability topics. This is in line with the business characteristics of universities which have more social performance. To improve sustainability performance in the future, universities must focus on improving performance in the environmental field.

The next measurement of sustainability performance used in this research is the STARS System performance measurement which developed by AASHE. Performance measurement with the STARTS System focuses on measuring sustainability performance at higher education institutions.

Table 2. The Result Using the GASU Method

\begin{tabular}{lcc}
\hline $\begin{array}{c}\text { Sustainability } \\
\text { Performance }\end{array}$ & $\begin{array}{c}\text { Percentage of } \\
\text { Information Disclosed }\end{array}$ & $\begin{array}{c}\text { The Ratio of } \\
\text { Information Disclosed }\end{array}$ \\
\hline Profile & 41.9 & 0.419 \\
Economic & 22.0 & 0.220 \\
Environment & 40.0 & 0.400 \\
Social & 80.0 & 0.800 \\
Education & 62.0 & 0.620 \\
Inter-linking issues and dimensions & 39.0 & 0.390 \\
\hline
\end{tabular}

Source: Processed Data, 2019 


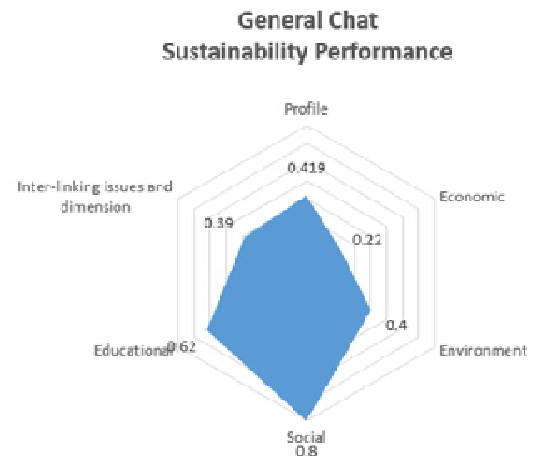

Figure 2. The Results of the Analysis of Sustainability Performance using the GASU Method

Source: Processed Data, 2019

The performance measurement indicators on the STARS System are intended to carry out sustainability performance assessments for organizations in the education sector. In this research, the measurement of sustainability performance at Universitas Pendidikan Ganesha uses a checklist provided from the STARS System performance measurement. In general, there are five categories of measurement of sustainability performance, namely (1) academics (AC), (2) engagement (EN), (3) operations (OP), (4) planning and administration (PA), and (5) innovation and leadership (IN). The academics category explains indicators of sustainability in the context of the education and teaching process at the university. The engagement category describes indicators of sustainability in the context of the university's relations with students and the relationship of the university with its social community. The operations category describes sustainability indicators in the context of university operations and the planning and administration category explains indicators in the context of university planning and administration.

Based on the Table 3. it can be seen that the largest ratio is in the academic category. This shows that the university has had a good sustainability performance in the field of education, especially in providing material on the concept of sustainability and research and publications related to the topic of sustainability. The university also has a good sustainability performance in the planning and administration fields, especially in creating a good work environment.

The results of this analysis show similarity with the results of the analysis of the GASU guidelines where the university does not have a good sustainability performance in the field of engagement and the field of operations. The university does not have a training program related to the concept of sustainability and in the field of operations, the university does not yet have guidelines in waste management.

Table 3. The Result Using the STARS System

\begin{tabular}{lrr}
\hline \multicolumn{1}{c}{ Sustainability Performance } & $\begin{array}{c}\text { Percentage of } \\
\text { Information Disclosed }\end{array}$ & $\begin{array}{c}\text { The Ratio of } \\
\text { Information Disclosed }\end{array}$ \\
\hline Academics & 63.6 & 0,636 \\
Engagement & 28.6 & 0,286 \\
Operations & 35.3 & 0,353 \\
Planning and Administration & 45.5 & 0,455 \\
\hline
\end{tabular}

Source: Processed Data, 2019 


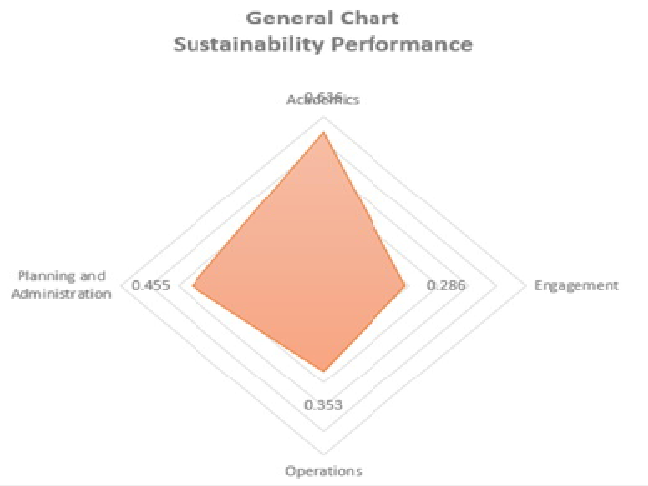

Figure 3. The Results of the Analysis of Sustainability Performance using the STARS System

Source: Processed Data, 2019

The results of this content analysis can be used to assess and evaluate the sustainability performance of the Universitas Pendidikan Ganesha. In the academic field, the university already has a curriculum that includes materials related to sustainability. Subjects related to the topic of sustainability are social and environmental accounting contained in the accounting study program. Support for the topic of sustainability is also manifested in the form of research by conducting research related to the concept of sustainability. The concept of sustainability has not been much realized in the university's operational activities. The university does not yet have policies and procedures related to waste treatment and energy policies. Nonetheless, the university has an excellent sustainability performance in the social field. The university has established cooperation with fostered villages and social communities. The university also has strong attention and commitment to the work environment and the health and safety of employees.

Based on the results of content analysis and conclusions from Richardson \& Kachler (2016), this research concludes that basically the Universitas Pendidikan Ganesha has had sufficient sustainability performance. The university has good sustainability performance in the education and social fields. A higher effort is needed to improve the university's sustainability performance in the environmental field. The sustainability performance of Universitas Pendidikan Ganesha is in the position of middle performance (between high and low). If the university wants to improve the performance of sustainability, the university must improve performance on points not yet achieved (environmental performance).

Sustainability reporting is a type of reporting that focuses on presenting financial and non-financial information for all organizational stakeholders. The function of sustainability reporting is very important to build good communication between the organization's leaders and the organization's stakeholders. The university leaders must understand that the main purpose of sustainability reporting is to provide confidence to university stakeholders that all university activities have been based on the concept of sustainability (Richardson \& Kachler, 2016). An et al. (2017) states that the concept and implementation of sustainability reporting at public universities is at the infancy stage and has not yet become a university reporting trend. Research conducted by An et al. 
(2017) tried to do an analysis of sustainability reports compiled by universities in New Zealand.

At this stage, this research tries to create a sustainability reporting framework for Universitas Pendidikan Ganesha. Universitas Pendidikan Ganesha has not prepared and reported financial information and non-financial information in the form of university sustainability reports. An et al. (2017) developed a framework for university sustainability reporting based on GRI G4 guidelines and the characteristics of information contained in the University of Canterbury's sustainability report. The framework resulting from the research of An et al. (2017) focuses on environmental aspects and consists of 15 metric measures. This framework is the basis for selecting environmental performance information that will be disclosed in the Universitas Pendidikan Ganesha's sustainability report. It must be understood that the selection of environmental performance information is highly dependent on the characteristics of the Universitas Pendidikan Ganesha.

To obtain preliminary information about the specific information needed by each stakeholder group, this research has conducted interviews with several representatives of the stakeholder groups. In the first stage, researchers conducted interviews with representatives of student stakeholder groups. The results of an interview with one of the students from the Faculty of Economics stated that

"During this time, students find it difficult to access information about scholarships and services provided by the university to students. We hope that information about scholarships and job fairs will be more widely shared with students."

The results of interviews with these students indicate that all these time students need specific information about scholarships, the amount of scholarships that can be accepted by students and academic and non-academic services that can be provided by the university to students. Another type of information needed by students is information about careers or job fairs. Information about careers or job fairs is nonfinancial information that must be provided by the university to students. Interviews were also conducted with one of the staff representatives. Interviews were conducted to obtain a perspective on the specific information needed by employee stakeholder groups. The results of an interview with one of the employees in the university's rectorate section stated that

"I, personally, do not really consider the information or performance of universities in the field of environmental conservation. For me information about the career and employee recruitment process is very important. We need information about a clear career path, the concept of reward and punishment and performance measurement."

Based on interviews with representatives of the university's internal stakeholder groups, it is interesting that the specific information needed is qualitative information and tends to support individual decision making. Specific information related to the university's environmental performance is also not an issue or important information for the university's internal stakeholder groups. This fact is inversely proportional to the results of An et al. (2017) which states that a university sustainability report in New Zealand reveals a good environmental performance. Some arguments can be raised why information about environmental performance does not become specific information 
needed by internal university stakeholders. These reasons are (1) the business line of the Universitas Pendidikan Ganesha is engaged in education and this field tends not to pollute the environment with significant impacts, (2) the university's internal stakeholder groups do not need information about the university's environmental performance because it is not used in the decision-making process that is still individual, and (3) the absence of organizational commitment to make the environmental performance as the of the focuses of university performance. This stage is the stage for identifying specific information that can be disclosed by the university if later it will make a university sustainability report. The type of information that will be disclosed at this stage is very dependent on the characteristics of the university and the information needs required by university stakeholders. To determine this specific type of information, the main basis or reference is based on the results of interviews, observations, and results of document analysis (mainly documents from other universities' sustainability reports).

The sustainability reporting process which carried out by the Universitas Pendidikan Ganesha directly will provide great benefits for the internal business processes of the university. Another benefit is that the sustainability process will improve the relationship between the university and university stakeholders (Mader, Scott, \& Abdul Razak, 2013). We must understand that universities must get the full support from the university stakeholders. All well-intentioned university policies can be informed to stakeholders through the university's sustainability reporting process.

Based on the scheme that has been prepared, this process begins with the flow of information, both financial and non-financial information, from the internal party of the university to all stakeholders of the university.

Sustainability accounting practices that will later be applied within the university can help the university to prepare information well. One important information that can be generated is about the picture of the sustainability performance of the university. The better of sustainability accounting practice is carried out within the organization, the better of the quality of information that will be generated.

Table 4. The Material Information on University Sustainability Report

\begin{tabular}{|c|c|c|}
\hline $\begin{array}{c}\text { Sustainability Performance } \\
\text { Indicator }\end{array}$ & Stakeholder Groups & $\begin{array}{l}\text { Specific Information and } \\
\text { Material Information }\end{array}$ \\
\hline Financial or & Internal Stakeholder & The university's revenue \\
\hline Economic & External Stakeholder & $\begin{array}{l}\text { The university budgeting process } \\
\text { The stakeholder engagement in } \\
\text { university budgeting process }\end{array}$ \\
\hline Social & $\begin{array}{l}\text { Internal Stakeholder } \\
\text { External Stakeholder }\end{array}$ & $\begin{array}{l}\text { The future plan from the } \\
\text { university social responsibility } \\
\text { The improvement in education } \\
\text { process } \\
\text { The support program for local } \\
\text { people and local village } \\
\text { The budget for the social } \\
\text { community }\end{array}$ \\
\hline Environmental & $\begin{array}{l}\text { Internal Stakeholder } \\
\text { External Stakeholder }\end{array}$ & $\begin{array}{l}\text { The commitment in energy and } \\
\text { water efficiency } \\
\text { The commitment in green } \\
\text { building and renewable energy }\end{array}$ \\
\hline
\end{tabular}

Source: Processed Data, 2019 


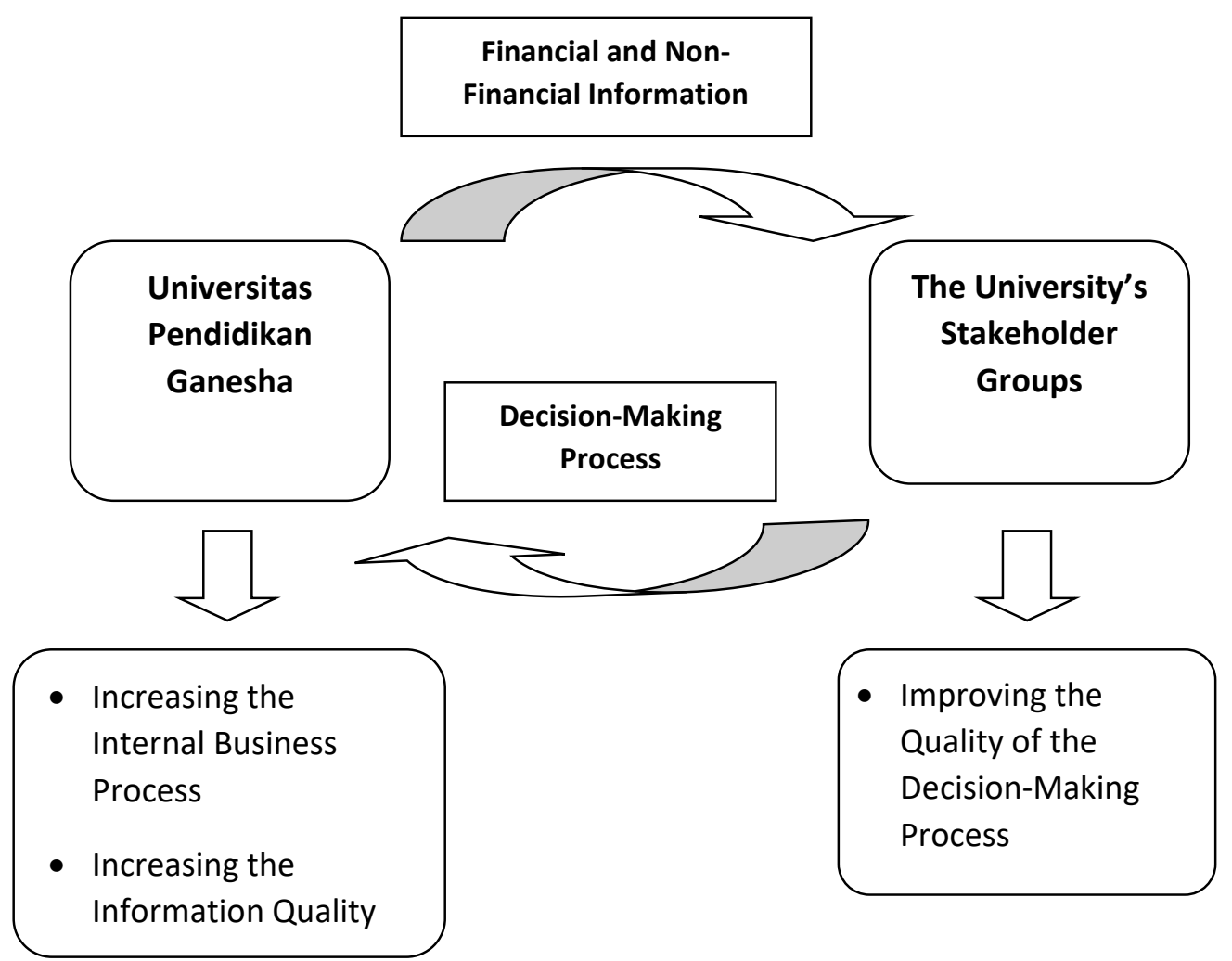

Figure 4. The Benefit of Sustainability Reporting Process

Source: Processed Data, 2019

This process will then continue when university stakeholders receive information that has been produced by the university (Amran \& Keat Ooi, 2014). This information will later be used by stakeholders in the context of decision-making process. This process will provide benefits for the university and university stakeholders. For the university, this sustainability reporting process will further enhance the commitment of university management to carry out sustainability accounting practices in organizational activities. Another benefit is that sustainability practices will be applied directly to daily activities within the organization and this process will improve the quality of internal business processes within the university. Another benefit to be gained by the university is the increase in the quality of information generated from the internal university. And the university's management can use the social media to promote their sustainability report (Manetti \& Bellucci, 2016). So far, the university has produced a lot of good quality information, but this type of information has not indicated that the university has been implementing sustainability accounting practices. And in the future, the university's management should promote the concept of integrated reporting in their curriculum and this step is important to promote the sustainability concept in academic community (Owen, 2013).

The main objective of this research is to develop a model for implementing sustainability accounting in educational sector organizations. The discussion section in this research has discussed a number of things that can be done so that the process of 
implementing sustainability accounting concepts and practices can be applied at Universitas Pendidikan Ganesha. In general, the model of implementing sustainability accounting in a tertiary education organization can be divided into four stages, namely (1) evaluating the existing accounting system, (2) identifying sustainability activities within the university, (3) evaluating university sustainability performance by using the GASU method or STARS System, and (4) preparing a university sustainability report.

The implementation model in the first stage carried out the process of evaluating the existing accounting system that is currently being run within the university. This process is important to see the accounting rules and accounting practices that are being applied in the organization. The next process is to identify sustainability activities that are currently being implemented within the university. One example of this stage is the process of identifying whether the university has recorded social costs and environmental costs. The process of identifying sustainability activities can be carried out based on guidelines issued by SASB. The next stage of the implementation model is the process of evaluating the university's sustainability performance. The sustainability performance assessment process is carried out to evaluate the sustainability accounting practices carried out within the organization. This process can be done with the help of GASU and STARS System. The next stage of the implementation model is to develop a concept of sustainability reporting that will be carried out by the university.

The sustainability reporting stage is the next important stage in the sustainability accounting implementation model. This stage is the stage of informing the university's sustainability performance to all university stakeholders. In this stage, university management must be able to choose specific types of information needed by university stakeholders. And also, the implementation of sustainability accounting in Universitas Pendidikan Ganesha will reflect the commitment of the university's management to build the university's plan with the concept of Tri Hita Karana. If the university's management has the high effort to implement the sustainability accounting concept, it means the university's sustainability performance will increase significantly and the university's vision and mission will be achieved as soon as possible.

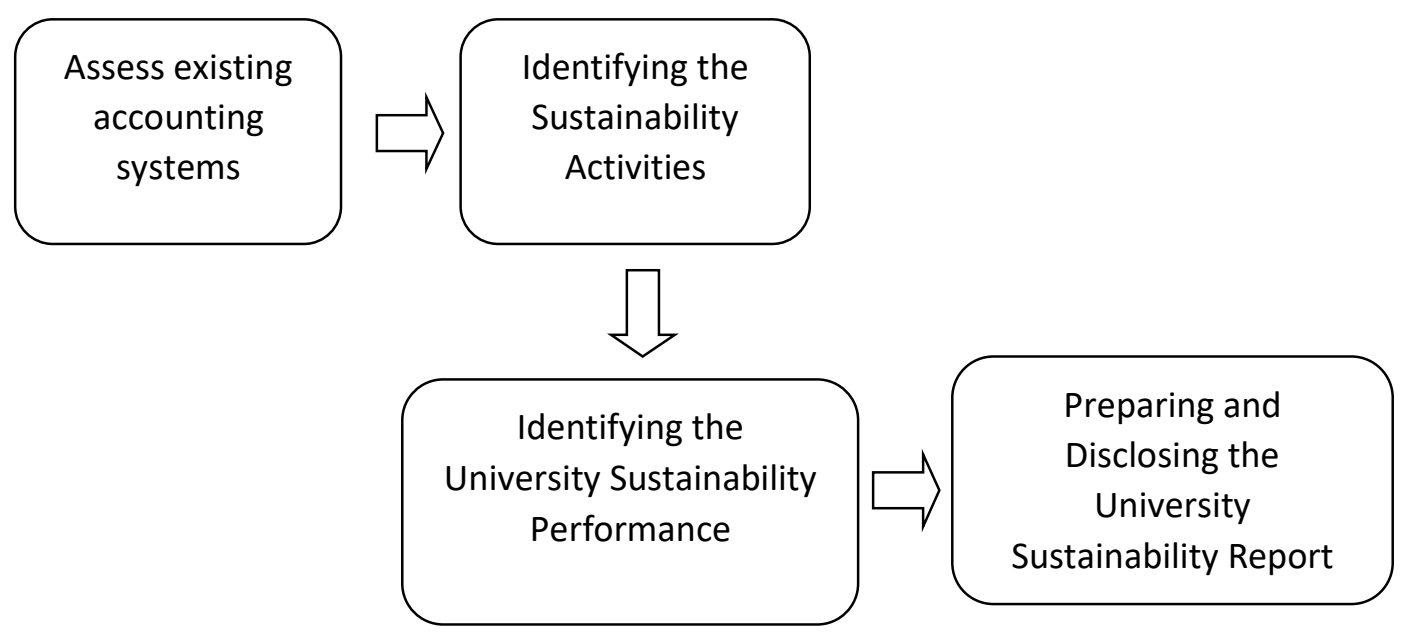

Picture 5. The Model for Implementing the Sustainability Concept in University Source: Processed Data, 2019 
The context of this research is still limited in the preparation of models or frameworks for the implementation of the concept of sustainability accounting in universities. The next stage in this research in the future is to implement the model that has been produced from this research. It must be understood that the implementation process of this model is very much determined based on the policies of the university leadership and the existence of relevant rules from the government that govern the application of sustainability accounting for public universities. Some parts of the model which generated from this research can also be directly applied to the company's internal business processes because it is a renewal of the accounting practices that have been carried out within the university.

\section{Conclusion}

This research is a conceptual research that aims to develop a model or framework for implementing the concept of sustainability accounting in an educational sector organization (public university). The application of the concept of sustainability accounting for an organization is very important to improve the quality of internal business processes contained in the organization. This research focuses on identifying accounting activities at Universitas Pendidikan Ganesha which can be included in a model or framework for implementing the concept of sustainability accounting at universities. This study concludes that the concepts and practices of sustainability accounting can be applied to an education sector organization (public university). It must be understood that the implementation process of the concept and practice of sustainability accounting requires a guideline or framework that can be used as a guideline in the implementation process. This research has produced a model or framework that can be used by university leaders in the context of the implementation of sustainable accounting concepts and practices.

The results of this research indicate that the Universitas Pendidikan Ganesha has a high ability and capability to implement the concepts and practices of sustainability accounting. In the future, the university leaders must continue to strive to improve the performance of the university. Improving the performance of the university environment will demonstrate the commitment of university leaders to carry out university activities based on the concept of sustainability. At present, Universitas Pendidikan Ganesha has had a good sustainability performance in the context of education and research. In the future, the university can improve its sustainability performance on other indicators of sustainability. To support in the context of improving the university's sustainability performance, the university management can form or create a unit or section that has a special duty to develop the concept of sustainability in university activities. The existence of a unit or section that focuses on the application of the concept of sustainability within the university's organizational structure will further enhance the university's commitment and vision in the context of sustainability. And for the future, it is possible to the university's management (or the public sector organization) to disclose the university's carbon information (Gibassier \& Schaltegger, 2015). If the public sector organization (including the public university) release their carbon information disclosure, it means the management of the public sector organization has a high effort to implement the sustainability concept. 


\section{Kurniawan}

Sustainability Accounting Concept in Higher Education Institution: A Case Study of an Indonesian Public University

The process of implementing sustainability accounting in Universitas Pendidikan Ganesha requires support from outside parties, particularly the support from the all university stakeholders. There must be a synergy between the university and all university stakeholders to support the process of implementing the concept of sustainability accounting. The university stakeholders can conduct monitoring related to the university's sustainability performance in the future. This monitoring process is not only to ensure that the concept of sustainability has been implemented within the university, but also to enhance a positive relationship between the interests of the university and the interests of the university's stakeholder groups. The monitoring process by the university stakeholders is needed to maintain and supervise so that all policies and activities carried out within the university are in line with the goals of the university. With this understanding, all university stakeholders have a great responsibility to help achieve the university's goals.

\section{References}

A. Adams, C., Muir, S., \& Hoque, Z. (2014). Measurement of sustainability performance in the public sector. Sustainability Accounting, Management and Policy Journal, 5(1), 46-67. https://doi.org/10.1108/SAMPJ-04-2012-0018

Adams, C. A. (2013). Sustainability reporting and performance management in universities: Challenges and benefits. Sustainability Accounting, Management and Policy Journal. https://doi.org/10.1108/SAMPJ-12-2012-0044

Amran, A., \& Keat Ooi, S. (2014). Sustainability reporting: meeting stakeholder demands. Strategic Direction, 30(7), 38-41. https://doi.org/10.1108/SD-03-2014-0035

An, Y., Davey, H., Harun, H., An, Y., Davey, H., \& Harun, H. (2017). Sustainability Reporting at a New Zealand Public University: A Longitudinal Analysis. Sustainability, 9(9), 1529. https://doi.org/10.3390/su9091529

Cohn, E., \& Geske, T. G. (1990). The economics of education. United States of America: Pergamon Press.

Domingues, A. R., Lozano, R., Ceulemans, K., \& Ramos, T. B. (2017). Sustainability reporting in public sector organisations: Exploring the relation between the reporting process and organisational change management for sustainability. Journal of Environmental Management, 192, 292-301. https://doi.org/10.1016/j.jenvman.2017.01.074

Farneti, F., \& Guthrie, J. (2009). Sustainability reporting by Australian public sector organisations: Why they report. Accounting Forum. https://doi.org/10.1016/j.accfor.2009.04.002

Gibassier, D., \& Schaltegger, S. (2015). Carbon management accounting and reporting in practice. Sustainability Accounting, Management and Policy Journal, 6(3), 340365. https://doi.org/10.1108/SAMPJ-02-2015-0014

Kaur, A., \& Lodhia, S. (2018). Stakeholder engagement in sustainability accounting and reporting. Accounting, Auditing \& Accountability Journal, 31(1), 338-368. https://doi.org/10.1108/AAAJ-12-2014-1901

Lange, E. A., \& Kerr, S. G. (2013). Accounting and incentives for sustainability in higher education: An interdisciplinary analysis of a needed revolution. Social Responsibility Journal. https://doi.org/10.1108/SRJ-08-2011-0058 


\section{Kurniawan}

Sustainability Accounting Concept in Higher Education Institution: A Case Study of an Indonesian Public University

Lozano, R. (2006). A tool for a Graphical Assessment of Sustainability in Universities (GASU). Journal of Cleaner Production, 14(9-11), 963-972.

https://doi.org/10.1016/J.JCLEPRO.2005.11.041

Lozano, R. (2011). The state of sustainability reporting in universities. International Journal of Sustainability in Higher Education, 12(1), 67-78. https://doi.org/10.1108/14676371111098311

Mader, C., Scott, G., \& Abdul Razak, D. (2013). Effective change management, governance and policy for sustainability transformation in higher education. Sustainability Accounting, Management and Policy Journal. https://doi.org/10.1108/SAMPJ-09-2013-0037

Manetti, G., \& Bellucci, M. (2016). The Use of Social Media for Engaging Stakeholders in Sustainability Reporting. Accounting, Auditing \& Accountability Journal, 29(6), 985-1011. https://doi.org/10.1108/AAAJ-08-2014-1797

Nickie Petcharat, N., \& Mula, J. M. (2012). Towards a conceptual design for environmental and social cost identification and measurement system. Journal of Financial Reporting and Accounting, 10(1), 34-54. https://doi.org/10.1108/19852511211237435

Owen, G. (2013). Integrated Reporting: A Review of Developments and their Implications for the Accounting Curriculum. Accounting Education. https://doi.org/10.1080/09639284.2013.817798

Richardson, A. J., \& Kachler, M. D. (2016). University sustainability reporting: a review of the literature and development of a model. In Handbook on sustainability in management education. University of Windsor. 